\title{
Pure androgen secreting adrenal adenoma: a case report and review of literature
}

Goto Gangkak*, Suresh Yadav, Shashi Verma, Neeraj Agarwal, Sher Singh Yadav and Vinay Tomar

*Correspondence: ggoto2003@yahoo.co.in

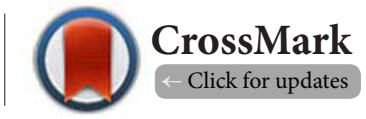

Department of Urology and Renal Transplant, Sawai Man Singh Medical College and Attached Hospitals, Jaipur, Rajasthan, India.

\begin{abstract}
Pure androgen secreting Adrenal adenoma is exceptionally rare. Till now only around 20 cases of exclusively androgen secreting adrenal adenomas have been reported in English literature. These tumours may present with virilisation, hirsutism, menstrual abnormalities and even infertility. Various hormonal characteristic including rare presentation of responsiveness to gonadotrophins have been reported. We present here our rare case of virilising purely androgen secreting adrenal adenoma in a 32 year old female and review of literature.
\end{abstract}

Keywords: HCG, androgen, adrenal, pure, adenoma, rare

\section{Introduction}

Virilising tumors in adult females typically arises from ovaries. Adrenal tumor causing virilisation is rare. Among them exclusively androgen secreting tumors are even rarer [1]. Usually adrenocortical carcinoma may present with symptoms of cortisol excess and virilisation. Adrenal adenoma presenting with exclusive androgen production is exceptionally rare. Till now only around 20 cases of exclusively androgen secreting adrenal adenomas have been reported in English literature. These tumors may present with various hormonal characteristics including rare presentation of responsiveness to gonadotrophins being reported. We present here our rare case of a purely androgen secreting adrenal adenoma in a female patient and review of literature.

\section{Case presentation}

A 32 year old married female presented with infertility since 2 years and hirsutism, irregular menses, masculine voice since 1 year. She complained of increased hair growth all over her body, mostly on face for which she had to shave daily and she also developed alopecia. She was moderately built and normotensive. On examination, she had male type of pubic hair distribution with clitoromegaly. She did not have any cushingoid features. Laboratory investigations showed serum testosterone level $1.76 \mathrm{ng} / \mathrm{ml}$ (0.09-1.09). Dihyrdoepiandrosterone sulphate (DHEA-S) was found to be raised $1082.2 \mathrm{ug} / \mathrm{dl}$ (74-410). Serum cortisol was normal. Serum estradiol was 0.26 $\mathrm{nmol} / \mathrm{L}(0.25-0.40)$ and serum androstenedione was $7 \mathrm{nmol} / \mathrm{L}$
(1.9-8.9). Low dose dexamethasone suppression test value was $6.40 \mathrm{ug} / \mathrm{dl}$, which was equivocal. Serum follicle stimulating hormone $(\mathrm{FSH})$ and Luteinising hormone $(\mathrm{LH})$ values were normal. Plasma free metanephrine was $29 \mathrm{pg} / \mathrm{ml}(<90)$. Plasma Nor-metanephrine was $32.7 \mathrm{pg} / \mathrm{ml}(<180)$. Urinary VMA was normal 1.04 mg/day (1.6-7.3). Fasting blood sugar was $71 \mathrm{mg} /$ dl. Ultrasonography showed a well defined, hypoechoic, solid encapsulated left suprarenal mass. Endovaginal scan was normal. Computed tomography (CT scan) Abdomen revealed a 9* $8 \mathrm{cms}$ moderately enhancing heterogenous suprarenal mass on left side (Figure 1).

Based on these findings, patient underwent left open Adrenalectomy (Figure 2). Histopathology report came out to be adrenal adenoma (Figure 3). Post-op patient recovered well. On follow up at 4 months her testosterone and DHEA-S values also normalized. Her hirsutism completely disappeared as well as her voice also recovered. She was having regular menstruation and now planning for conception.

\section{Discussion}

Virilisation in females can be due to virilisation. Tumors secreting excessive androgen leads tovirilisation and other symptoms of androgen excess [1]. Tumors causing virilisation usually originate in ovary. Less commonly, adrenal tumors are responsible for virilisation and usually an adrenocortical carcinoma is the culprit [1]. They are associated with elevated urinary 17-ketosteroid (17-KS) levels and high concentrations 


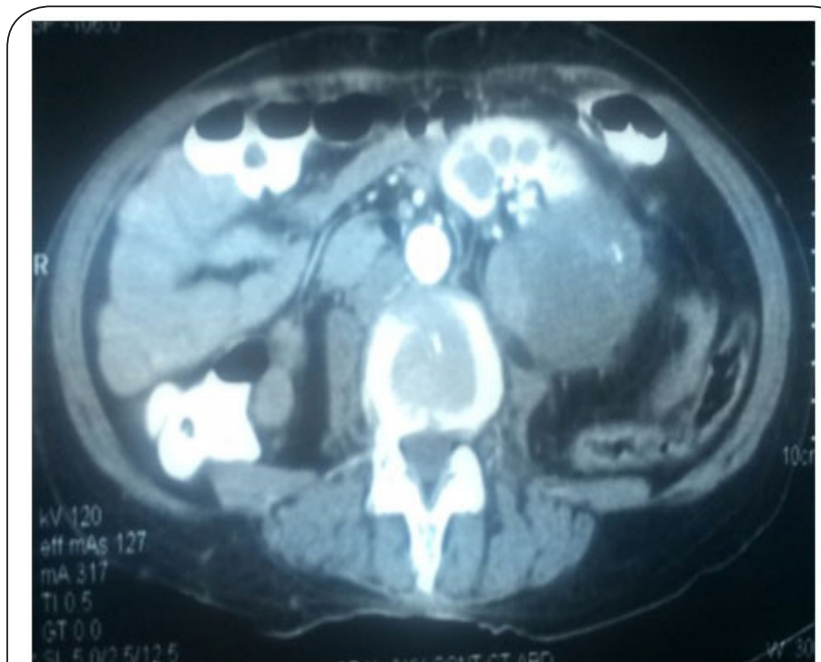

Figure 1. CT scan showing left heterogenous enhancing adrenal mass.

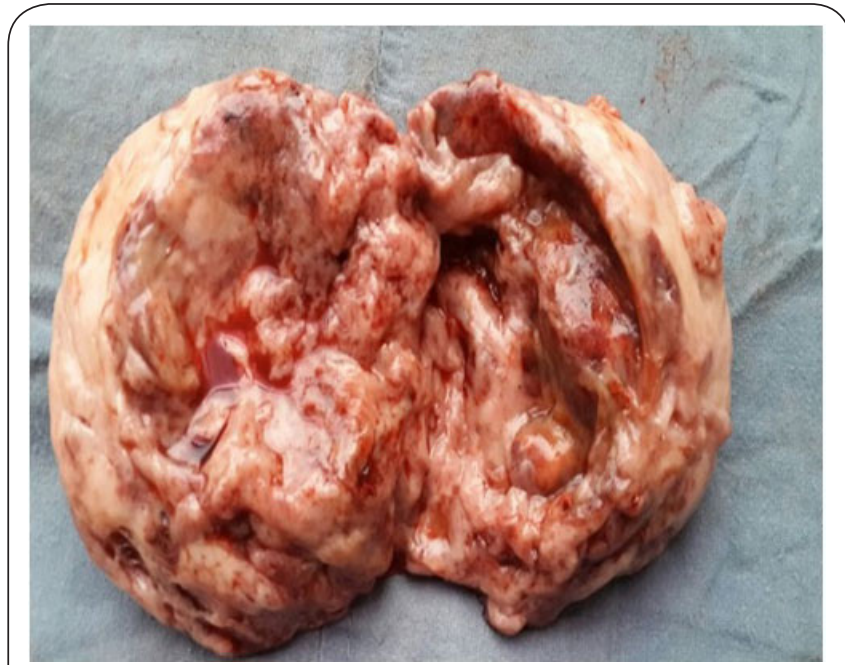

Figure 2. Cut section of the specimen showing hemorrhagic areas.

of dehydroepiandrosterone (DHEA), androstenedione and testosterone [2]. Normally the adenal cortex secretes DHEA, androstenedione and estrone (17-ketosteroids, 17-KS). Ovary and testis secrete estradiol and testosterone. Thus, the finding of high levels of testosterone usually points to an ovarian source. However virilisation can also occur with adrenal tumors due to secretion of androstenedione and DHEA (leading to high 17-KS levels), which are peripherally converted to testosterone [1]. Most of the reported testosterone secreting adrenal adenoma are associated with increased urinary 17KS due to increased secretion of DHEA [3]. Adrenal tumors secreting purely androgens without cortisol and elevated levels of 17-KS are a rarity and pure androgen secreting
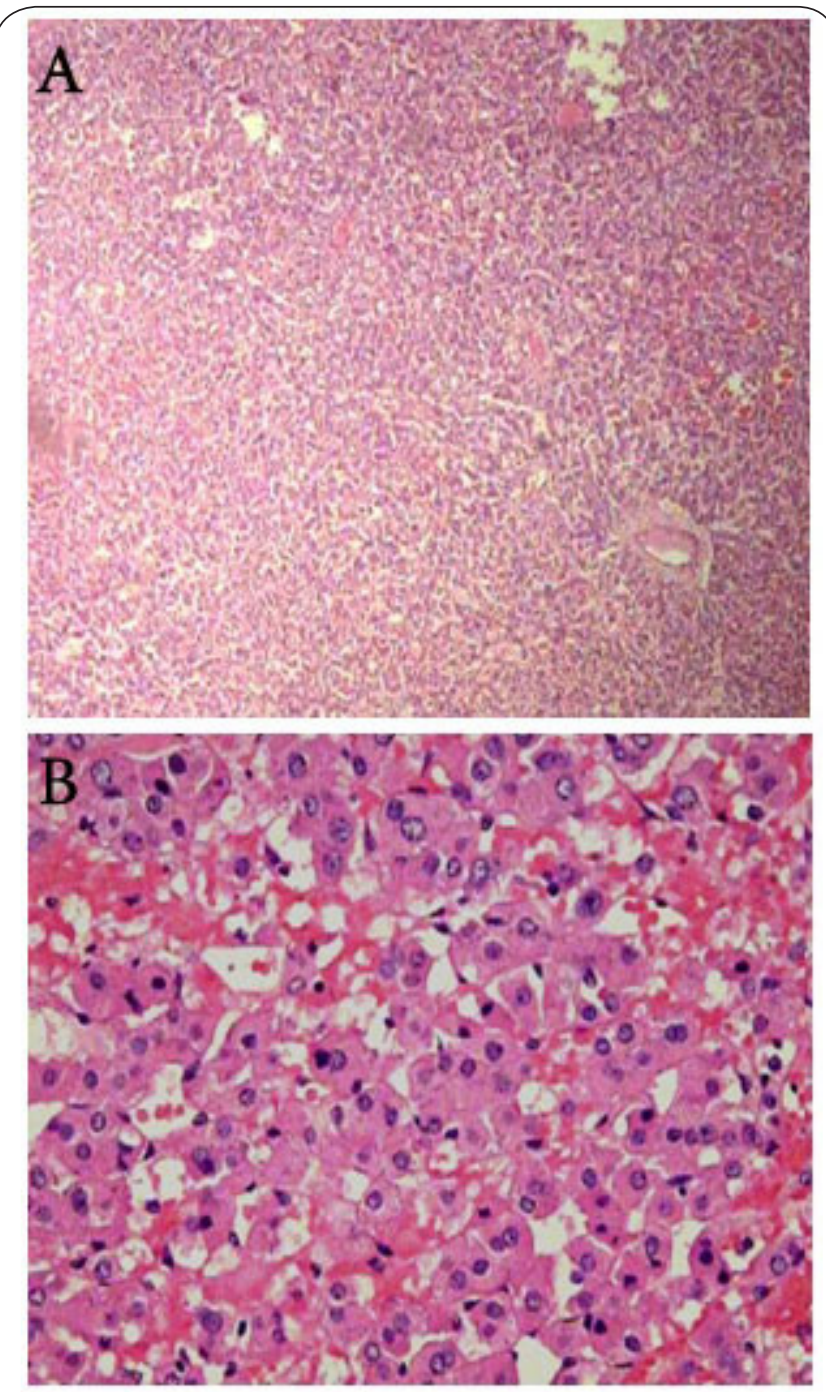

Figure 3. (A) Low magnification H\&E stain. Round to oval cells arranged in trabeculae, nesting and alveolar pattern. Large areas of hemorrhage seen.

(B) High magnification H\&E stain. Round to oval cells with vacuolated lipid rich cytoplasm seen. Few cells showing anisonucleosis. Features consistent with Adrenal adenoma. adenomas are even rarer. Givens et al., had proposed that the excess serum testosterone with low 17-KS is due to increased enzymatic activity in virilizing adrenal tumours converting the androstenedione (the prevailing adrenal androgen) into testosterone [4]. Kelly et al., also made the observation that there was 50 fold increase in 17-P-hydroxysteroid dehydrogenase activity in the tumor, thus converting androstenedione directly into testosterone [5]. Aguirre and Scully'o theorised that the pure testosterone secreting adrenal tumors might have originated from gonadal cells displaced within the adrenal gland [6]. Vasiloff et al., further supported this theory by finding crystalloids specific for gonadal Leydig cells in three cases of virilizing adrenal tumors [7]. 
Givens et al., were one of the earliest to report a case of purely testosterone secreting adrenal adenoma. The patient had only elevated serum testosterone with normal urinary 17-KS. Dexamethasone suppression test also did not lower the testosterone levels and gonadotrophins increased the testosterone level. The patient underwent bilateral oophorectomy, as an ovarian source was suspected but the testosterone levels were still elevated post-oophorectomy. So the patient underwent adrenal exploration and a $4 \mathrm{~cm}$ adrenal tumor was removed which turned out to be an adrenal adenoma [4]. Leinonen et al., also reported on the paradoxical responsiveness of adrenal adenoma to gonadotrophins and demonstrated Human chorionic gonadotrophins (HCG) receptors in the adenoma specimen [8]. Similar gonatrophin responsive tumors were also reported by many authors [2,9-11]. Moreno et al., from Lille, france presented their report of 21 cases of Pure Androgen secreting adrenal tumours ( PASATs) in a review of 801 adrenalectomies over a period of 33 years. They found that only 6 patients had adrenal adenoma with the pure androgen secreting profile, which is the largest reported series in English literature. They also concluded that $50 \%$ of PASATs are malignant and no biochemical parameter is suggestive of malignancy. All patients had undergone imaging studies and underwent open adreneclectomies [12]. Cordera et al., from mayo clinic recently performed their review of virilising adrenal tumors from january 1946 to November 2002 in which only 2 such cases were reported [1]. The authors concluded that imaging studies are the best method to diagnose the tumour and surgical resection is the standard treatment.

Before the advent of imaging studies like computed tomography scan (CT Scan), Ultrasonography and Magnetic resonance imaging (MRI), we had to rely on dynamic hormonal testing to differentiate adrenal from ovarian source [13].
Dexamethasone suppression test, ACTH/HCG stimulation test were done to find the cause and source of androgen excess $[13,14]$. However dynamic hormonal testing has been challenged as a means of differentiating between the two sources of hormone production in view of varied tumor responsiveness to hormones and subset of gonadotrophin responsive tumors $[4,7,8]$. The results of dynamic hormonal testing can be misleading, as too many unnecessary oophorectomies have been performed in literature when the real culprit was the adrenal tumour $[4,5,15-17]$. Currently the best method to differentiate between adrenal and ovarian source is by modern radiologic techniques such as Ultrasonography, CT Scan, MRI and venous sampling [1]. Modern Imaging techniques can reliably localize the tumor and are currently the investigation of choice for tumor localization and staging. In our case, high serum testosterone level made us to suspect an ovarian source first but the endovaginal scan turned out to be normal and dexamethasone test was equivocal. So we did an abdominal sonography and could find the adrenal tumor on ultrasonography and CT Scan.

Surgical resection remains the primary treatment modality of choice for virilising adrenal tumors. Traditionally open transperitoneal adrenalectomy was the standard procedure of choice but with the advent of laparoscopy, virilising adrenal tumors are being successfully resected laparoscopically much frequently. Prognosis is excellent with surgical Therapy. Postoperatively patients need to be monitored with serial imaging and biochemical tests [1].

To the best of our knowledge, only 20 cases of purely androgen secreting adrenal adenoma have been reported in the English literature so far. If we include case reports with slightly elevated 17-KS another five cases can be included [7]. We have presented all the reported cases with the relevant biochemical profile, treatment and outcome in the Table 1.

Table 1. Showing various clinical and biochemical parameters with treatment outcome of reported patients.

\begin{tabular}{|c|c|c|c|c|c|c|c|c|c|c|}
\hline Author & $\begin{array}{l}\text { Age in } \\
\text { years }\end{array}$ & Sex & Presentation & $\begin{array}{l}\text { Serum } \\
\text { Testosterone }\end{array}$ & $\begin{array}{l}\text { Serum } \\
\text { DHEA-S }\end{array}$ & 17-KS & $\begin{array}{l}\text { HCG } \\
\text { responsive }\end{array}$ & $\begin{array}{l}\text { Tumor } \\
\text { size/side }\end{array}$ & Treatment & $\begin{array}{l}\text { Outcome/ } \\
\text { follow up }\end{array}$ \\
\hline Givens et al., & 49 & $\mathrm{~F}$ & Virilisation & $911 \mathrm{ng} / \mathrm{dl}$ & -- & $\mathrm{N}$ & + & $4 \mathrm{cms} / \mathrm{R}$ & $\begin{array}{l}\text { Oopherectomy } \\
+ \\
\text { Adrenalrectomy }\end{array}$ & $\begin{array}{l}\text { Virilisation } \\
\text { reduced/NA }\end{array}$ \\
\hline $\begin{array}{l}\text { Larson et al., } \\
{[\mathbf{1 8}]}\end{array}$ & 76 & $\mathrm{~F}$ & Virilisation & $9130 \mathrm{pg} / \mathrm{ml}$ & - & $\begin{array}{l}8.6 \mathrm{mg} / \\
24 \mathrm{hrs}\end{array}$ & & NA & Adrenalectomy & Alive \& Well \\
\hline $\begin{array}{l}\text { Cordera et } \\
\text { al., }\end{array}$ & $27 / 52$ & $\mathrm{~F}$ & NA & Elevated & - & $\mathrm{N}$ & NA & $\begin{array}{l}6 \mathrm{c} \mathrm{ms} / \mathrm{R} \\
1.5 \\
\mathrm{cms} / \mathrm{L}\end{array}$ & Adrenalectomy & $\begin{array}{l}6 \text { months and } \\
118 \text { months, } \\
\text { live and well }\end{array}$ \\
\hline $\begin{array}{l}\text { Dolinar } \\
\text { et al., [19] }\end{array}$ & 60 & $\mathrm{~F}$ & Virilisation & $650 \mathrm{pg} / \mathrm{ml}$ & $2100 \mathrm{nmol} / \mathrm{l}$ & $\begin{array}{l}7.2 \mathrm{mg} / \\
24 \text { hours }\end{array}$ & - & - & $\begin{array}{l}\text { Oopherectomy- } \\
\text { adrenalectomy }\end{array}$ & $\begin{array}{l}\text { Decreased } \\
\text { testosterone }\end{array}$ \\
\hline Moreno et al., & $\begin{array}{l}6 \\
\text { patients } \\
(17-66)\end{array}$ & $\mathrm{F}$ & $\begin{array}{l}\text { Hirsutism in } \\
\text { all, infertility } \\
\text { in } 2 \text { patients }\end{array}$ & Elevated & Elevated & $\mathrm{N}$ & NA & $\begin{array}{l}(4 \mathrm{cms} \\
-22 \mathrm{cms})\end{array}$ & Adrenalectomy & $\begin{array}{l}\text { Testosterone } \\
\text { normalized in } \\
\text { all, } 2 \text { died of } \\
\text { stroke \& CML } \\
\text { FU ( } 1 \text {-33 years) }\end{array}$ \\
\hline
\end{tabular}


Continuation of Table 1.

\begin{tabular}{|c|c|c|c|c|c|c|c|c|c|c|}
\hline Author & $\begin{array}{l}\text { Age in } \\
\text { years }\end{array}$ & Sex & Presentation & $\begin{array}{l}\text { Serum } \\
\text { Testosterone }\end{array}$ & $\begin{array}{l}\text { Serum } \\
\text { DHEA-S }\end{array}$ & 17-KS & $\begin{array}{l}\text { HCG } \\
\text { responsive }\end{array}$ & $\begin{array}{l}\text { Tumor } \\
\text { size/side }\end{array}$ & Treatment & $\begin{array}{l}\text { Outcome/ } \\
\text { follow up }\end{array}$ \\
\hline $\begin{array}{l}\text { Kable et al., } \\
{[20]}\end{array}$ & - & $\mathrm{F}$ & Virilisation & $472 \mathrm{ng} / \mathrm{dl}$ & - & $\begin{array}{l}14.9 \mathrm{mg} / 24 \\
\mathrm{hrs}\end{array}$ & $\mathrm{NA}$ & - & Adrenalectomy & Alive and well \\
\hline La'szlo et al., & 55 & $\mathrm{~F}$ & Virilisation & $7.6 \mathrm{ng} / \mathrm{ml}$ & $220 \mathrm{nmol} / \mathrm{l}$ & $3.6 \mathrm{nmol} / \mathrm{l}$ & + & $3 \mathrm{cms} / \mathrm{R}$ & $\begin{array}{l}\text { Flutamide } \\
\text { Adrenelactomy }\end{array}$ & $\begin{array}{l}\text { Hirsutism } \\
\text { decreased at } 4 \\
\text { months }\end{array}$ \\
\hline $\begin{array}{l}\text { Spaulding } \\
\text { et al., [21] }\end{array}$ & - & $\mathrm{F}$ & Virilisation & $500 \mathrm{ng} / \mathrm{dl}$ & $\mathrm{N}$ & 7.3 & & $1 \mathrm{~cm} / \mathrm{R}$ & $\begin{array}{l}\text { Laparoscopy } \\
\text { and } \\
\text { adrenalectomy }\end{array}$ & NA \\
\hline $\begin{array}{l}\text { Rodríguez } \\
\text { Gutiérrez } \\
\text { et al., [22] }\end{array}$ & 18 & $\mathrm{~F}$ & $\begin{array}{l}\text { Virilisation } \\
\text { and } \\
\text { hypertension }\end{array}$ & $4.3 \mathrm{ng} / \mathrm{ml}$ & $1000 \mathrm{u} / \mathrm{dl}$ & $25 \mathrm{ng} / \mathrm{dl}$ & NA & $10 \mathrm{cms} / \mathrm{L}$ & Adrenalectomy & $\begin{array}{l}\text { Alive and off } \\
\text { anti hyperten- } \\
\text { sive drugs at } 2 \\
\text { months }\end{array}$ \\
\hline Kelly et al., & - & $\mathrm{F}$ & Virilisation & $285 \mathrm{ng} / \mathrm{dl}$ & $\mathrm{N}$ & $\mathrm{N}$ & - & - & Adrenalectomy & Alive and well \\
\hline $\begin{array}{l}\text { Leinonen } \\
\text { et al., }\end{array}$ & 60 & $\mathrm{~F}$ & Virilisation & $17.8 \mathrm{nmol} / \mathrm{l}$ & $630 \mathrm{nmol} / \mathrm{l}$ & NA & + & NA/R & $\begin{array}{l}\text { Hysterectomy, } \\
\text { B/L } \\
\text { oopherectomy, } \\
\text { adrenelectomy }\end{array}$ & NA \\
\hline $\begin{array}{l}\text { Themis et al., } \\
{[23]}\end{array}$ & 15 & $\mathrm{~F}$ & Virilisation & elevated & $\mathrm{N}$ & $\mathrm{N}$ & - & - & Adrenalectomy & $\begin{array}{l}\text { Attained } \\
\text { puberty and } \\
\text { menses at } 4 \\
\text { months }\end{array}$ \\
\hline Vasiloff et al., & 49 & $\mathrm{~F}$ & Virilisation & $1408 \mathrm{ng} / \mathrm{dl}$ & NA & $\begin{array}{l}11.1 \mathrm{mg} / 24 \\
\mathrm{hrs}\end{array}$ & - & $4 \mathrm{cms} / \mathrm{R}$ & adrenalectomy & NA \\
\hline Smith et al., & 50 & $\mathrm{~F}$ & virilisation & $970 \mathrm{ng} / \mathrm{dl}$ & $2300 \mathrm{nmol} / \mathrm{l}$ & $\begin{array}{l}11.2 \mathrm{mg} / 24 \\
\text { hours }\end{array}$ & + & NA & Adrenelecto,y & NA \\
\hline Current case & 32 & $\mathrm{~F}$ & $\begin{array}{l}\text { Viruilisation, } \\
\text { infertility }\end{array}$ & $1.76 \mathrm{ng} / \mathrm{ml}$ & $1082 \mathrm{ug} / \mathrm{dl}$ & $\mathrm{N}$ & - & $9 \mathrm{cms} / \mathrm{L}$ & Adrenlectomy & $\begin{array}{l}\text { Decease in } \\
\text { hirsutism, } \\
\text { normal } \\
\text { testosterone at } \\
4 \text { months }\end{array}$ \\
\hline
\end{tabular}

\section{Conclusion}

Pure androgen secreting adrenal adenoma is a very rare presentation. Dynamic endocrine testing cannot be relied upon for its diagnosis. Radiological imaging studies are currently the standard tests for localizationnd diagnosis along with endocrinologic studies. Surgical resection remains the standard treatment.

\section{List of abbreviations}

DHEA-S: Dihyrdoepiandrosterone sulphate

FSH: Follicule stimulating hormone

LH: Luteinising hormone

CT scan: Computedtomography

17-KS: 17-ketosteroid

HCG: Human chorionic gonadotrophins

PASATs: Pure androgen secreting adrenal tumours

MRI: Magnetic resonance imaging

\section{Competing interests}

The authors declare that they have no competing interests.
Authors' contributions

\begin{tabular}{|l|c|c|c|c|c|c|}
\hline Authors' contributions & GG & SY & SV & NA & SSY & VT \\
\hline Research concept and design & $\checkmark$ & -- & -- & -- & -- & -- \\
\hline Collection and/or assembly of data & -- & $\checkmark$ & $\checkmark$ & -- & -- & -- \\
\hline Data analysis and interpretation & -- & -- & -- & -- & -- & -- \\
\hline Writing the article & $\checkmark$ & $\checkmark$ & -- & -- & -- & -- \\
\hline Critical revision of the article & -- & -- & -- & $\checkmark$ & $\checkmark$ & -- \\
\hline Final approval of article & $\checkmark$ & -- & -- & -- & -- & $\checkmark$ \\
\hline
\end{tabular}

Acknowledgement

I would like to thank our patient for giving consent for case reporting and her cooperation during the whole process.

Publication history

Editors: Andrew Z. Fenves, Massachusetts General Hospital, USA. Matthew E. Nielsen, University of North Carolina at Chapel Hill, USA. Received: 26-May-2015 Final Revised: 26-Jun-2015

Accepted: 10-Jul-2015 Published: 23-Jul-2015

\section{References}

1. Cordera F, Grant C, van Heerden J, Thompson G and Young W. Androgensecreting adrenal tumors. Surgery. 2003; 134:874-80. | Article | PubMed 
2. Schteingart DE, Woodbury MC, Tsao HS and McKenzie AK. Virilizing syndrome associated with an adrenal cortical adenoma secreting predominantly testosterone. Am J Med. 1979; 67:140-6. | Article | PubMed

3. Murphy BEP. Clin Endocrinol Metab. 1967; 27:973.

4. Givens JR, Andersen RN, Wiser WL, Coleman SA and Fish SA. A gonadotropin-responsive adrenocortical adenoma. J Clin Endocrinol Metab. 1974; 38:126-33. | Article | PubMed

5. Kelly TR, Mayors DJ and Boutsicaris PS. Adrenal adenoma. Isolated testosterone secretion. Am Surg. 1982; 48:604-6. | Article | PubMed

6. Aguirre $P$ and Scully RE. Testosterone-secreting adrenal ganglioneuroma containing Leydig cells. Am J Surg Pathol. 1983; 7:699-705. | PubMed

7. Vasiloff J, Chideckel EW, Boyd CB and Foshag LJ. Testosterone-secreting adrenal adenoma containing crystalloids characteristic of Leydig cells. Am J Med. 1985; 79:772-6. | Article | PubMed

8. Imai T, Tobinaga J, Morita-Matsuyama T, Kikumori T, Sasano H, Seo $\mathrm{H}$ and Funahashi $\mathrm{H}$. Virilizing adrenocortical adenoma: in vitro steroidogenesis, immunohistochemical studies of steroidogenic enzymes, and gene expression of corticotropin receptor. Surgery. 1999; 125:396-402. | Article | PubMed

9. Leinonen P, Ranta T, Siegberg R, Pelkonen R, Heikkila P and Kahri A. Testosterone-secreting virilizing adrenal adenoma with human chorionic gonadotrophin receptors and 21-hydroxylase deficiency. Clin Endocrinol (Oxf). 1991; 34:31-5. | Article | PubMed

10. Smith HC, Posen S, Clifton-Bligh P and Casey J. A testosterone-secreting adrenal cortical adenoma. Aust N Z J Med. 1978; 8:171-5. | Article | PubMed

11. Loszio FA, Toth S, Kocsis J, Pavo and Szecsi M. Testosterone-secreting gonadotropin-responsive adrenal adenoma and its treatment with the antiandrogen flutamide. J Endocrinol Invest. 2001; 24:622-7. | Article | PubMed

12. Moreno S, Montoya G, Armstrong J, Leteurtre E, Aubert S, Vantyghem $M C$, Dewailly D, Wemeau JL and Proye C. Profile and outcome of pure androgen-secreting adrenal tumors in women: experience of 21 cases. Surgery. 2004; 136:1192-8. | Article | PubMed

13. Derksen J, Nagesser SK, Meinders AE, Haak HR and van de Velde CJ. Identification of virilizing adrenal tumors in hirsute women. $N$ Eng/ J Med. 1994; 331:968-73. | Article | PubMed

14. Del Gaudio AD and Del Gaudio GA. Virilizing adrenocortical tumors in adult women. Report of 10 patients, 2 of whom each had a tumor secreting only testosterone. Cancer. 1993; 72:1997-2003. | Article | PubMed

15. Trost BN, Koenig MP, Zimmermann A, Zachmann M and Muller J. Virilization of a post-menopausal woman by a testosterone-secreting Leydig cell type adrenal adenoma. Acta Endocrinol (Copenh). 1981; 98:274-82. | Article | PubMed

16. Werk EE, Jr., Sholiton LE and Kalejs L. Testosterone-secreting adrenal adenoma under gonadotropin control. N Engl J Med. 1973; 289:767-70. | Article | PubMed

17. de Lange WE, Pratt JJ and Doorenbos $\mathrm{H}$. A gonadotrophin responsive testosterone producing adrenocortical adenoma and high gonadotrophin levels in an elderly woman. Clin Endocrinol (Oxf). 1980; 12:21-8. | Article | PubMed

18. Larson BA, Vanderlaan WP, Judd HL and McCullough DL. A testosteroneproducing adrenal cortical adenoma in an elderly woman. J Clin Endocrinol Metab. 1976; 42:882-7. | Article | PubMed

19. Dolinar $\mathrm{R}$ and Burch WM. Testosterone-producing adrenal adenoma in a woman with normal urinary 17-ketosteroid levels. JAMA. 1983; 250:2504-5. | Article | PubMed

20. Kable WT and Yussman MA. Testosterone-secreting adrenal adenoma. Fertil Steril. 1979; 32:610-1. | PubMed

21. Spaulding SW, Masuda T and Osawa Y. Increased 17 beta-hydroxysteroid dehydrogenase activity in a masculinizing adrenal adenoma in a patient with isolated testosterone overproduction. J Clin Endocrinol Metab. 1980; 50:537-40. | Article | PubMed

2. Rodriguez-Gutierrez R, Bautista-Medina MA, Teniente-Sanchez AE,
Zapata-Rivera MA and Montes-Villarreal J. Pure androgen-secreting adrenal adenoma associated with resistant hypertension. Case Rep Endocrinol. 2013; 2013:356086. | Article | PubMed Abstract | PubMed Full Text

23. Kamilaris TC, DeBold CR, Manolas KJ, Hoursanidis A, Panageas S and Yiannatos $\mathrm{J}$. Testosterone-secreting adrenal adenoma in a peripubertal girl. JAMA. 1987; 258:2558-61. | Article | PubMed

\section{Citation:}

Gangkak G, Yadav S, Verma S, Agarwal N, Yadav SS and Tomar V. Pure androgen secreting adrenal adenoma: a case report and review of literature. Clin Nephrol Urol Sci. 2015; 2:2. http://dx.doi.org/10.7243/2054-7161-2-2 